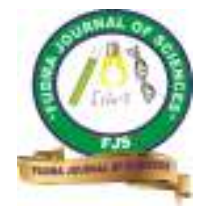

FUDMA Journal of Sciences (FJS)

ISSN online: $2616-1370$

ISSN print: 2645 - 2944

Vol. 5 No. 1, March, 2021, pp $511-516$

DOI: https://doi.org/10.33003/fjs-2021-0501-597

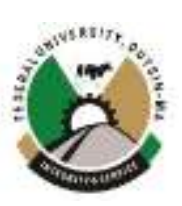

\title{
ASSESSMENT OF FIBRE CHARACTERISTICS OF SPONDIA MOMBIN L. (ANACARDIACEAE) FOR PULP AND PAPER PRODUCTION
}

Tembe, E. T., *Ekhuemelo, D. O. and Aondoaver, B. T.

Department of Forest Production and Products, Federal University of Agriculture Makurdi, Nigeria

*Corresponding Author's Email: davidekhuemelo@gmail.com

\begin{abstract}
The fibre characteristics of five Spondia mombin stands were studied to determine their suitability for pulp and paper production. Wood slivers obtained parallel to grain at three (3) different positions along the bole were macerated in combined identical amounts of glacial acetic acid plus hydrogen peroxide under heat at between 80-100o C. Macerated fibres were washed clean of mixture and mounted on slide for microscopic examination of fibre characteristics. Completely Randomized Design (CRD) was employed for the experiment. Data were analysed using one-way Analysis of Variance (ANOVA) while, the Duncan's Multiple Range Test (DMRT) was used to separate means of significant differences among the treatments. Results show that significant differences existed in fibre characteristic of sampled trees, however the fibre length ranged from 0.98-1.0 mm, fibre diameter (18.22-21.47 um), lumen width (10.90-12.98 um) and cell wall thickness (3.86-4.60 um). Significant differences were also observed among the derived fibre characteristics, the Runkel ratio ranged from $0.66-8.89$, elasticity coefficient (57.22-60.50\%), coefficient of rigidity (19.78-22.24 \%), slenderness ratio (43.27-46.5). This implied that, the fibres of S. mombin were short and elastic which make the wood species an appropriate raw material for pulp and paper making especially when blended with other long fibre species.
\end{abstract}

Keywords: Wood slivers, Glatial acetic acid, Fibre Characteristics, Derived Fibre indices

\section{INTRODUCTION}

S. mombin L. belong to the family Anacardiaceae. In Englishspeaking countries, it is called yellow mombin, hog plum; in Spanish it is known as jobo or ciruela amarilla (Andall and Paull, 2012). Medicinally, all portions of the $S$. mombin are noted to be very important (Uchendu and Isek, 2008). Spondia mombin is a hardwood species that its pulp characteristic has not been fully studied. The tree is grown mostly for its ornamental qualities of beautification in homes and recreation centres and for its broad shade at maturity.

However, pulp is a mass of fibres obtained by macerating wood from lingo-cellulose materials, while, paper is commonly known as thin layer of fibres which is manufactured from the process of pressing together the cellulose fibre of pulp obtained from either wood, rags or grasses, and subjecting it to hot drying. Paper has a wide variety of utilization which includes production of writing paper, printing and packaging purposes. Paper can also be used for cleaning purposes, decorations and a host of other industrial and construction services (Ogunleye et al., 2017).

Over the years, Pinus species have remained the conventional raw materials for long fibre pulp, while short fibre pulp is sourced mainly from hardwood species like Gmelina arborea, Hevea brasiliensis and Terminalia species among others, most of the pulpwood materials are sourced from plantations across the world (Izekor and Fawape, 2011; Tembe et al., 2015, 2020). Continuous exploitation of long and short fibre pulp wood species has caused severe depletion in the available stock in plantations and coupled with competition of the same wood resources for other end users, there is overwhelming shortfall in pulpwood supply. Therefore, there is an urgent need to explore other wood resources as alternative sources of pulpwood to the traditional/indigenous species that are already depleting in our plantations. The study is therefore aimed at identifying the fibre characteristics of Spondia mombin and its derived characteristics to determine its suitability for use as a material for pulp and paper making.

\section{MATERIALS AND METHODS}

Study Area

Federal University of Agriculture, Makurdi Benue State, Nigeria was the study site. The university is located at Latitude $07^{\circ} 45^{\prime}$ $07^{\circ} 50^{\prime} \mathrm{N}$, Longitudes $08^{\circ} 45^{\prime}-08^{\circ} 50^{\prime} \mathrm{E}$, of the Greenwich Meridian and elevation $98 \mathrm{~m}$ (Obiora et al., 2015). The study area falls within Guinea savannah with sparse vegetation. The area experiences two different seasons which are rainy or wet and dry or summer seasons. The rainy season spans from AprilOctober with the annual rainfall ranging from $1000 \mathrm{~mm}$ to 1500 $\mathrm{mm}$. The dry season starts from November to March, while, the temperature changes from $23^{\circ} \mathrm{C}$ to $37^{\circ} \mathrm{C}$.

\section{Sample Collection and Preparation}

Samples were collected from five different trees of $S$. mombin, the Diameter at Breast Height $(\mathrm{DBH})$ of samples tree were determined using diameter tape, wood slivers obtained along the grain of tree samples were taken from the base, middle and the top at $5 \%, 50 \%$ and $90 \%$ of the main bole of samples trees respectively. The wood silvers were pulped in a mixture of glacial acetic acid $\left(\mathrm{CH}_{3} \mathrm{COOH}\right)$ and hydrogen peroxide $\left(\mathrm{H}_{2} \mathrm{O}_{2}\right)$ 
at the same volume under $80^{\circ} \mathrm{C}-100^{\circ} \mathrm{C}$ for 2 hours. The pulped wood fibres were rinsed and sample placed on microscopic slides and lay on a Zeiss light microscope (standard 25). Fifteen (15) cellulose fibres were randomly selected and examined for fibre characteristics on each slide.

Then derived fibre characteristics calculated include:

Where:

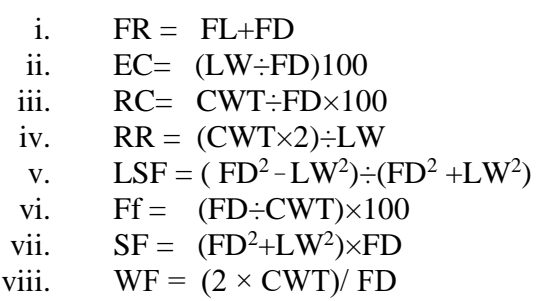

FL - Fibre length;

FD - Fibre diameter;

LW - Lumen width;

WT - Cell wall thickness;

FR/S - Felting rate/slenderness;

EC - Elasticity coefficient;

$\mathrm{RC}$ - Rigidity coefficient,

RR - Runkel ratio;
Ff - F factor (\%);

$\mathrm{SF}$ - Solids factor;

LSF - Luce's shape factor;

WF - Wall fraction.

Experimental Design and Data Analysis

Completely Randomized Design (CRD) was used for this study. Data were analysed using one way Analysis of Variance (ANOVA) on Statistical Package for the Social Sciences (SPSS, version 20) to determine whether means of fibre characteristics and its derivatives among sample trees were significant or not. The means that were significant were followed up with a test using Duncan's Multiple Range Test (DMRT) (Duncan, 1955).

\section{RESULTS}

Fibre morphology of Spondia mombin

The mean values of fibre morphology of $S$. mombin were presented in Table 1. Means of fibre length were not significantly different at $p>0.05$. Means of fibre diameter were highest $(0.98 \mu \mathrm{m}-1.00 \mu \mathrm{m})$ in $\mathrm{T} 5$ and lowest $(18.22 \mu \mathrm{m})$ in $\mathrm{T} 2$. Lumen width mean values were highest $(12.98 \mu \mathrm{m})$ in T3 and lowest $(10.90 \mu \mathrm{m})$ in T2. Mean values of cell wall thickness were $4.62 \mu \mathrm{m}$ and $3.86 \mu \mathrm{m}$ respectively. Mean values of $S$. mombin fibre diameter, lumen width and cell wall thickness were not significantly different $(p>0.05)$ among number trees sampled.

Table 1: Fibre morphology of Spondia mombin Species

\begin{tabular}{|c|c|c|c|c|c|}
\hline \multirow{2}{*}{$\begin{array}{l}\text { Number of } \\
\text { Tree }\end{array}$} & \multirow[t]{2}{*}{ DBH (m) } & Fibre Length & Fibre Diameter & Lumen Width & Cell Wall Thickness \\
\hline & & Mean \pm Sdv & Mean \pm Sdv & Mean \pm Sdv & Mean \pm Sdv \\
\hline T1 & 0.76 & $0.98 \pm 0.149$ & $20.11 \pm 4.001^{\mathrm{b}}$ & $11.76 \pm 3.955^{\mathrm{ab}}$ & $4.40 \pm 1.136^{b}$ \\
\hline $\mathrm{T} 2$ & 0.51 & $0.98 \pm 0.141$ & $18.22 \pm 3.872^{\mathrm{a}}$ & $10.90 \pm 3.046^{\mathrm{a}}$ & $3.86 \pm 1.340^{\mathrm{a}}$ \\
\hline T3 & 0.36 & $1.00 \pm 0.000$ & $21.47 \pm 5.417^{b}$ & $12.98 \pm 4.989^{b}$ & $4.31 \pm 1.184^{\mathrm{ab}}$ \\
\hline $\mathrm{T} 4$ & 0.39 & $0.98 \pm 0.149$ & $20.53 \pm 3.894^{b}$ & $11.47 \pm 3.514^{\mathrm{ab}}$ & $4.62 \pm 0.83^{b}$ \\
\hline T5 & 0.32 & $0.98 \pm 0.149$ & $21.20 \pm 4.625^{\mathrm{b}}$ & $12.13 \pm 3.811^{\mathrm{ab}}$ & $4.60 \pm 1.214^{b}$ \\
\hline & Total & $0.98 \pm 0.131$ & $20.26 \pm 4.509$ & $11.83 \pm 3.928$ & $4.35 \pm 1.182$ \\
\hline
\end{tabular}

Means with the same alphabets on the same column are not significantly different $(\mathrm{p}>0.05)$

Derived indices of $S$. mombin

The results of derived indices from $S$. mombin in this study showed that wall coverage ratio had mean values of between 0.00 and 0.04 , Runkel ratio $(0.64$ and 0.89$)$ and elasticity coefficient $(55.60 \%$ and $60.50 \%)$. Means of rigidity coefficient was $19.78 \%$ to $22.24 \%$, slenderness ratio was 43.10 and $46.58 \%$, and Luce's Shape Factor was between 0.51 and 0.73 , F factor from 20.60 and 25.38, while, Solid factor had means of 295 to 346.29 , respectively (Table 2). The derived indices from S. mombin in this study were not significantly different $(\mathrm{p}>$ 0.05 ) among number of trees sampled.
Suitability of $S$. mombin for pulp and paper production Indices of fibre suitability of $S$. mombin for pulp and paper production are shown in Table 3. The result revealed that cellulose fibres of $S$. mombin are short $(0.32 \mathrm{~mm}-0.76 \mathrm{~mm})$ in length, while, the Runkel ratio indicated that the fibre are good for paper production since they are less than $1(0.64-0.89)$. The mean values of elasticity coefficient $(57.22 \%-60.50 \%)$ shown that the cellulose fibres were all elastic.

Microscopic photograph of cellulose of $S$. mombin

Figure 1 shows the cellulose fibre microscopy of $S$. mombin as viewed under a Zeiss light microscope. The cellulose fibre appeared short. 
Table 2: Derived indices of $S$. mombin

\begin{tabular}{|c|c|c|c|c|c|c|c|c|c|}
\hline \multirow[t]{2}{*}{$\begin{array}{l}\text { Numb } \\
\text { er of } \\
\text { Tree }\end{array}$} & \multirow[t]{2}{*}{$\begin{array}{l}\text { DBH } \\
\text { (m) }\end{array}$} & $\begin{array}{l}\text { Wall } \\
\text { Coverage } \\
\text { ratio }\end{array}$ & $\begin{array}{l}\text { Runkel } \\
\text { Ratio }\end{array}$ & $\begin{array}{l}\text { Elasticity } \\
\text { Coefficient (\%) }\end{array}$ & $\begin{array}{l}\text { Rigidity } \\
\text { Coefficient } \\
(\%)\end{array}$ & $\begin{array}{l}\text { Slenderness } \\
\text { ratio }(\%)\end{array}$ & $\begin{array}{l}\text { Luce's } \\
\text { Shape Factor } \\
\text { (LSF) }\end{array}$ & F factor & Solid Factor (SF) \\
\hline & & $\operatorname{Mean} \pm$ Sdv & Mean \pm Sdv & Mean \pm Sdv & Mean \pm Sdv & Mean \pm Sdv & Mean \pm Sdv & Mean \pm Sdv & Mean \pm Sdv \\
\hline $\mathrm{T} 1$ & 0.76 & $0.00 \pm 0.000$ & $0.89 \pm 0.318^{\mathrm{b}}$ & $57.22 \pm 11.186$ & $21.33 \pm 5.693$ & $46.58 \pm 12.643$ & $0.64 \pm 0.484$ & $20.60 \pm 16.833$ & $315.60 \pm 139.922$ \\
\hline $\mathrm{T} 2$ & 0.51 & $0.02 \pm 0.141$ & $0.66 \pm 0.688^{\mathrm{ab}}$ & $60.50 \pm 13.033$ & $19.78 \pm 6.554$ & $43.10 \pm 11.659$ & $0.54 \pm 0.503$ & $25.38 \pm 15.288$ & $295.06 \pm 131.704$ \\
\hline $\mathrm{T} 3$ & 0.36 & $0.02 \pm 0.149$ & $0.64 \pm 0.484^{\mathrm{a}}$ & $60.00 \pm 11.918$ & $20.04 \pm 5.947$ & $43.27 \pm 12.086$ & $0.51 \pm 0.506$ & $22.25 \pm 7.374$ & $335.00 \pm 138.303$ \\
\hline $\mathrm{T} 4$ & 0.39 & $0.02 \pm 0.149$ & $0.78 \pm 0.471^{\mathrm{ab}}$ & $55.60 \pm 10.076$ & $22.24 \pm 5.028$ & $43.98 \pm 9.944$ & $0.73 \pm 0.447$ & $21.22 \pm 8.509$ & $346.29 \pm 148.730$ \\
\hline \multirow[t]{2}{*}{ T5 } & 0.32 & $0.04 \pm 0.208$ & $0.78 \pm 0.517^{\mathrm{ab}}$ & $57.27 \pm 10.391$ & $21.33 \pm 5.205$ & $45.53 \pm 13.532$ & $0.60 \pm 0.495$ & $22.44 \pm 7.430$ & $338.76 \pm 144.578$ \\
\hline & Total & $0.02 \pm 0.146$ & $0.75 \pm 0.518$ & $58.17 \pm 11.463$ & $20.92 \pm 5.755$ & $44.46 \pm 11.995$ & $0.60 \pm 0.490$ & $22.45 \pm 11.944$ & $325.47 \pm 140.619$ \\
\hline
\end{tabular}

Note: Means with the same alphabets on the same column are not significantly different $(p>0.05)$

Table 3: Suitability of $S$. mombin for pulp and paper production

\begin{tabular}{|c|c|c|c|c|c|c|c|}
\hline $\begin{array}{l}\text { Number } \\
\text { of Tree }\end{array}$ & $\begin{array}{l}\text { DBH } \\
\text { (m) }\end{array}$ & $\begin{array}{l}\text { Fibre } \\
\text { length } \\
(\mathrm{mm})\end{array}$ & $\begin{array}{l}\text { Class of Fibre } \\
\text { Length }\end{array}$ & $\begin{array}{l}\text { Runkel } \\
\text { Ratio }\end{array}$ & $\begin{array}{l}\text { Ranking of } \\
\text { Runkel } \\
\text { Ratio }\end{array}$ & $\begin{array}{l}\text { Elasticity } \\
\text { Coefficient (\%) }\end{array}$ & $\begin{array}{l}\text { Class of } \\
\text { Elastic fibres }\end{array}$ \\
\hline T1 & 0.76 & 0.98 & Short & 0.89 & Good & 57.22 & Elastic fibres \\
\hline $\mathrm{T} 2$ & 0.51 & 0.98 & Short & 0.66 & Good & 60.50 & Elastic fibres \\
\hline $\mathrm{T} 3$ & 0.36 & 1.00 & Short & 0.64 & Good & 60.00 & Elastic fibres \\
\hline $\mathrm{T} 4$ & 0.39 & 0.98 & Short & 0.78 & Good & 55.60 & Elastic fibres \\
\hline $\mathrm{T} 5$ & 0.32 & 0.98 & Short & 0.78 & Good & 57.27 & Elastic fibres \\
\hline
\end{tabular}

Key:

High elastic fibres are $>75$; Elastic fibres are 50 to 75; rigid fibres are 30 - 50; High rigid fibre are < 30;

Fibre length $<1.60 \mathrm{~mm}$ are short fibres; Fibre length $>1.60 \mathrm{~mm}$ are long fibres;

Runkel ratio $<1$ are Good; Runkel ratio $>1$ are Not good for paper production

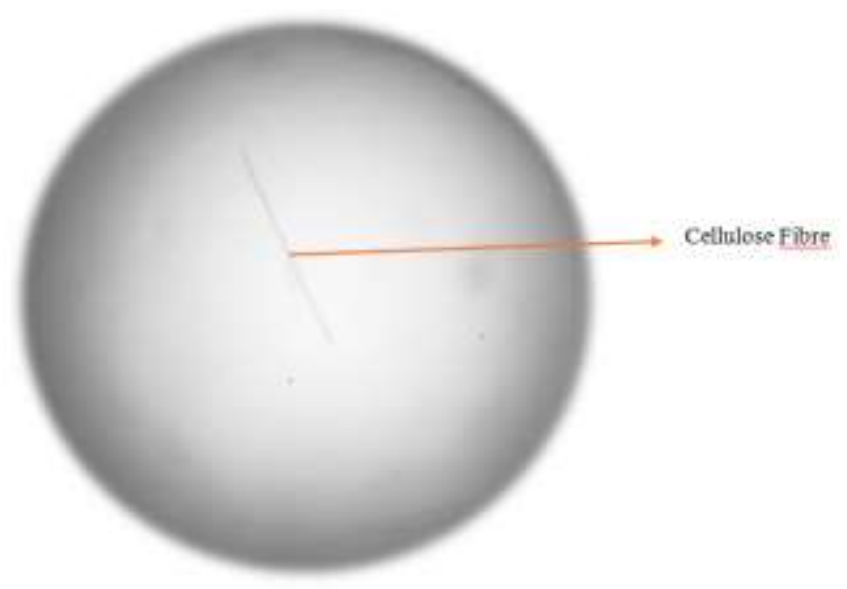

Figure 1: Microscopic photograph of cellulose of S. mombin

\section{DISCUSSION}

$S$. mombin mean fibre length recorded in this study were short fibres. This implies that $S$. mombin can be mixed with long fibre species to produce good quality paper. The mean of fibres length obtained in this study are within the values known for hardwood species. Metcalfe and Chalk (1983) and Anon (1984) categorised fibres less than $1.60 \mathrm{~mm}$ as being short whereas those longer than $1.60 \mathrm{~mm}$ in length are classified as long fibres. Fibres that have wide lumen with thin cell walls are likely to be flat like ribbons in the process of papermaking with better fibreto-fibre bond and between fibres. This scenario consequently gives good paper strength properties ( Osadare 2001). A perusal of literature reveals that hardwood fibres are shorter than softwood fibres and varies from $0.7-1.6 \mathrm{~mm}$ in hardwoods and 2.7 - $4.6 \mathrm{~mm}$ in softwoods (Ates et al., 2008). However, fibre length of $S$. mombin stem as obtained in this study is lower than the recommended fibre length for good quality pulp and paper. As a result, it will only produce good quality paper when blended with long fibre materials.

In this study, $S$. mombin fibre diameter values $(18.22-21.20$ $\mu \mathrm{m})$ fall within the range of $20-40 \mu \mathrm{m}$ fibre diameters for 
hardwood fibres reported by (Usta and Eroghe, 1987). The result obtained in this study is lower than 36.09 and $34.25 \mu \mathrm{m}$ recorded for Rhizophora racemosa and Rhizophora harrisonii by Emerhi (2012) and the values similar to what is that of tropical hard wood species. However, $S$. mombin diameter values are higher than the values of $18.69-28.93 \mu \mathrm{m}$ accounted fit for pulp and papermaking. The increase in fibre diameter in sampling height is related to the growing age of the tree could be due to some molecular and physiological variations which takes place within the vascular cambium and the increase in wood cell wall thickness during the tree growing period (Roger et al., 2007).

The means of $S$. mombin are within $13.0 \mu \mathrm{m}$ for $T$. grandis reported by Izekor and Fuwape (2011) and $13.0 \mu \mathrm{m}$ for $G$. arborea and $9.87 \mu \mathrm{m}$ in L. leucocephala by Ajala (1997). Furthermore the mean values are similar to $5.37-16.40 \mu \mathrm{m}$ reported for bast core and whole stalk of kenaf (Shakhes et al., 2011). Fibre lumen width influences the beating performance of pulp which implies that, as fibre lumen increased in width the beating of pulp becomes better because of the ease of chemical penetration into vascular spaces of cellulose fibres (Emerhi, 2012). The mean value of lumen fibre width of $S$. mombin in this study shows that $S$. mombin species will perform well during pulp beating up.

The means of cell wall thickness of Spondia mombin (3.86 - 4.62 $\mu \mathrm{m})$ in this study are similar to values $1.94-4.99 \mu \mathrm{m}$ for Ficus species reported by Ogunkunle (2010) and higher than $4.02 \mu \mathrm{m}$ values for G. arborea (Roger et al., 2007) and $4.64 \mu \mathrm{m}$ for $C$. pallid (Sharma et al., 2013). Papers made from fibres with thick cell wall are bulky, have rough appearance and possess huge amount of void volume (Mercy et al, 2017). Cellulose fibres that have thin cell wall have good formation and are dense, therefore, $S$. mombin species will be good for pulp and papermaking based on their cell wall thickness.

Runkel ratio mean values from $S$. mombin are similar to 0.79 recorded for tropical pine species by Ajala (1997); 0.99 both $A$. amacrophyia and $D$. guinensis hardwood species in Nigerian rainforest ecosystem by Ezeibekwe et al. (2009). Also, Bektas et al. (1999) reported that as Runkel ratio values increase, paper strength reduces which is relative to decrease burst, tear and tensile indexes of paper. Fibres that have Runkel ratio above one (1) produce very poor paper potential while Runkel ratio values below $1(<1)$ tend to have very good paper quality. Fibres that have high Runkel ratio values are usually stiff, low flexibility. This forms heavier papers that have low bounded surfaces compare to lower ratio fibre. Therefore, it might be considered that $S$. mombin will produce good paper.

S. mombin fibre in this study can be regarded as elastic because its elasticity coefficient ranged between 55.60 and 60.50. Fibres may be grouped into four classes based on their elasticity rates or values. These four classes include the following: high elastic fibres with mean values above $75 \%$; elastic fibres have coefficient values from $50-75$. Also, rigid fibres are within 30 $-50 \%$ while high rigid fibres have their values below $30 \%$ (Istas et al., 1954; Bektas et al., (1999). According to this grouping, $S$ mombin fibre being elastic implies that Spondia mombin is suitable for paper making.
Mean values of $S$. mombin rigidity coefficient from this study are similar to the value (22.95\%) reported by Hus et al. (1975) for juvenile beech wood. High values of rigidity coefficient negatively influence paper characteristics such as tensile strength tear strength, burst strength and double fold resistance of paper (Hus et al., 1975). Therefore, the paper produced from materials having low rigidity coefficient might possess low tensile strength, tear strength, burst strength and double fold resistance, hence are not appropriate raw material for pulp and paper making.

The result of $S$. mombin of Solid factor (235.40 - 380.27\%) in this study are comparable to the Solid factor reported for juvenile beech wood which was between 140.38 and $240.55 \%$ for juvenile wood of black pine species (Akgul and Tozluoglu, 2009). Solids factor influence paper sheet density and might be significantly correlated to breaking length of paper (Ona et al., 2001). Therefore, this implies that solid factor $S$. mombin is similar to that of beech juvenile wood.

The values of Luce's shape factor (0.51-0.73\%) obtained in this study are below $0.47 \%$ recorded for Afzelia africana and similar to $0.73 \%$ reported for Detarium senegalensis as report by Ojo (2013). Luce's shape factor of $0.20 \%$ (S. edule); $0.30 \%$ both for $C$. annum and $S$. melongena; $0.09 \%(G$. max) to 0.30 (C. sativus and $S$. edule) have been reported. It was also reported that Luce's shape factor are closely connected to the density of paper sheet and could be significantly correlated to breaking strength of paper.

Slenderness ratio result $(43.10-46.58 \%)$ obtained in this research are all lower than 50.06 for G. arborea and from 42.38 - 71.99 reported by Ogunkunle, (2010) for some Ficus species. Slenderness ratio determines the tearing property of paper. Slenderness ratio of fibres with high value gives good bonded and well formed paper (Ashori and Nourbakhsh, 2009). The slenderness ratio more than 33 for fibrous material is regarded better for pulp and papermaking (Xue et al., 2006). The selected species of agro waste materials show that $C$. sativus has highest slenderness ratio value of 54.63 and lowest (28.44) in G. Max. The low slenderness ratio in some of species may be due to presence of short fibres. Therefore $S$. mombin may be regarded to be very suitable for the production of pulp and paper since it has fibre materials more than 33 .

The mean values of wall coverage ratios obtained from Macaranga bancana and Macaranga pearsonii ranged from $0.07-0.08$ and from $0.07-0.10$ (Ryosuke et al., 2016) which are higher than 0.020 .04 recorded for $S$. mombin in this study. The values of wall coverage ratio in $S$. mombin as recorded in this study was between 0.02 and 0.04 values which implies that the species is a good candidate for paper making.

\section{CONCLUSION}

Fibre characteristics and derived morphology of S. mombin for pulp and paper making was clearly investigated viz-a-viz the fibre length, fibre diameter, lumen width, cell wall thickness, Runkel ratio, elasticity coefficient, rigidity coefficient, F factor, Luces's shape factor, solid factor, slenderness ratio/felting power which revealed that $S$. mombin is good for paper production. The wood species fibre fell into short fibre length 
and had elasticity coefficient greater than 50 and slenderness ratio greater than 33 , Runkel ratio was less than 1 which is within the accepted values for pulp and paper making. The rigidity of the fibre was low and this will enhance fibre bonding.

\section{REFERENCES}

Ajala, O. O. (1997). Evaluation of wood and fibre characteristics of Nigerian grown Pinus carribea, Department of Forest Resources Management, University of Ibadan, Ibadan, Nigeria. Thesis, Pp137.

Akgul, M. and Tozluoglu, A. (2009). Some Chemical and Morphological Properties of Juvenile Woods from Beech (Fagus orientalis L.) and Pine (Pinus nigra A.) Plantations. Trends in Applied Sciences Research, 4: 116-125.

Amidon, T. E. (1981). Effect of the wood properties of hardwoods on kraft paper properties. Tappi, 64: 123-126.

Andall, R. and Paull, R. E. (2012). Spondias mombin (Yellow mombin). In: The Encyclopedia of Fruit and Nuts. J. Janick and R. E. Paull, editors. CABI International, Cambridge, MA. P. 3134.

Anon (1984). Chemical Analysis of Nigerian Grown timbers. Annual Report of the Forestry Research Institute of Nigeria. Jan. - Dec., p. 108-109.

Ashori, A. and Nourbakhsh, A. (2009). Studies on Iranian cultivated Paulownia: a potential source of fibrous raw material for paper industry. European Journal of Wood and Wood Products, 67: 323-327.

Ates, S., Ni, Y., Akgul, M. and Tozluoglu, A. (2008). Characterization and evaluation of Paulownia elongata as a raw material for paper production. African Journal of Biotechnology, 7 (22): 4153 - 4158

Bektas, I, Titus, A. and Broglue, H. (1999). A study of the suitability of calabrain pine (pinusbrutiaten) for pulp and paper manufacture. Turkey Journal of Agriculture and Forestry, 23 589-599.

Dinwoodie, J. M. (1965). The relationship between fibre morphology and paper properties of: A Review of Literature. Tappi, 48: 440-447.

Duncan, D. B. (1955). Multiple Range and Multiple F- test Biometrics. 11:1-42.

Emerhi, E. A. (2012). Variations in anatomical properties of Rhizophoraracemosa (Leechm) and Rhizophora harrisonii (G. $\mathrm{Mey})$ in a Nigerian mangrove forest ecosystem. International Journal of Forest, Soil and Erosion, 2 (2): 89-96.

Ezeibekwe, I. O., Okeke, S. E., Unamba, C. I. and Ohaeri, J. C. (2009). An Investigation into the potentials of Dactyladenia bacteri; Dialum guineense; and Anthonotama crophylia for Paper Pulp Production. Report and Opinion, 1 (4): 18-25.
Hudson, I., Wilson,, L. and Beveren, K. V. (1998). Vessel and fiber property variation in Eucalyptus globulus and Eucalyptus nitens: some preliminary results. IAWA Journal, 19: 111-130.

Hus, S., Tank, T. and Goksal, E. (1975). Considering Eucalyptus (E: camaldulensis Dhnh). Wood which grow in Turkey (in Tarsus-Karabacak). Morphology and opportunity for evaluating semi chemical cellulose in paper industry. Tubitak Publication, USA.

Izekor, D. N. and Fuwape, J. A. (2011).Variations in the anatomical characteristics of plantation grown Tectona grand is wood in Edo State, Nigeria. Archives of Applied Science Research, 3 (1): 83-90.

Izekor, D. N. and Fuwape, J. A. (2011). Variations in the anatomical characteristics of plantation grown Tectona grandis wood in Edo State, Nigeria. Archives of Applied Science Research, 3 (1): 83-90.

Kami, P. G. K. (1969). Genboku 'Chouboku (Log and log preparation). Kami parupu gijutsu kyokai (Japan Technical Association of the Pulp and Paper Industry), Tokyo.

Mercy, O. B., Adeola, F. J., Olajide, O. A., Babatunde, A. and Sunday, F. J. (2017). Evaluation of fibre characteristics of Ricinodendron heudelotii (Baill, Pierre Ex Pax) for pulp and paper making. International Journal of Scientific and Technology Research, 6 (1): 634-641.

Metcalfe, C. R. and Chalk, L. (1983). Anatomy of the dicotyledons 2, 2. Nordic Journal of Botany, 4 (5): 668- 668.

Obiora, D. N., Ajala, A. E. and Ibuot, J. C. (2015). Investigation of groundwater flow potential in Makurdi, North Central Nigeria, using surficial electrical resistivity method. African Journal of Environmental Science and Technology, 9(9): 723733.

Ogunleye, B. M, Fuwape, J. A, Oluyege, A.O., Agayi, B. and Fabiyi, J. S. (2017). Evaluation of fibre characteristics of Ricinodedron heudelotic (bail, pierre ex pax) for pulp and paper making. International Journal of Science and Technology, 6(1): 684-636.

Ogunkunle, A. T. J. (2010). A Quantitative Modeling of Pulp and Paper Making Sustainability of Nigerian Hardwood Species. Advances in Natural and Applied Sciences, 4 (1): 1421.

Ojo, D. O. (2013). Determination of Pulp and Paper Making Suitability Indices of Some Nigerian Species of Leguminosae: Caesalpinoideae. Academic Journal of Interdisciplinary Studies, 2 (13): 61-68.

Oluwadare, A. O. (1998). Evaluation of the Fibre and Chemical Properties of some Selected Nigerian Wood and Non-wood species for Pulp Production. Journal of Tropical Forest Research, 14: 110-119. 27. 
Oluwadare, A. O. (1998). Evaluation of the Fibre and Chemical Properties of Some Selected Nigerian Wood and Non-Wood Species for pulp production. Journal of Tropical Forest Science, 14: $110-119$

Ona, T., Sonoda, T., Ito, K., Shibata, M., Tamal, Y., Kosima, Y., Ohshima, Yokota, S. and Yoshinzawa, N. (2001). Investigation of relationship between cell and pulp properties in Eucalyptus by examination of tree variations. World Science and Technology, 35: 229-243.

Osadare, A. O. (2001). Basic wood and pulp properties of Nigerian-grown Caribbean pine (Pinus caribaea Morelet) and their relationship with tree growth indices. Ph.D. thesis University of Ibadan. p.347.

Panshin, A. and De Zeeuw, C. (1980). Textbook of Wood Technology. 4th edition, McGrawth-Hill, New York. Pp 722.

Roger, M. R., Mario, T. F. and Edwin, C. A. (2007). Fiber morphology in fast growth Gmelina arborea plantations. Madera y Bosques, 13 (2): 3-13.

Shakhes, J., Zenaly, F, Marandi, M. A. B. and Sagafi, T. (2011). The effect of processing variable on the soda and soda $A Q$ pulping of kenafbastfibre, Bioresources, 6 (9): 4626-4639.

Sharma, M., Sharma, C. L. and Kumar, Y. B. (2013). Evaluation of fiber characteristics in some weeds of Arunachal Pradesh, India for pulp and paper making. Research Journal of Agriculture and Forestry Sciences, 1 (3): 15-21.
Takeuchi, R., Wahyudi, I., Aiso, H.,Ishiguri, F., Istikowati, W. T., Ohkubo, T., Ohshima, J., Iizuka, K. and Yokota, S. (2016). Wood properties related to pulp and paper quality in two Macaranga species naturally regenerated in secondary forests, Central Kalimantan, Indonesia, Tropics, 25 (3): 107-115.

Tembe, E. T., Amonum, J. I. and Shomkeg, S. A. (2010). Variations in fibre length of rubber wood (Hevea brasiliensis (kunth) Muel Arg) grown in south east Nigeria. Journal of Research in Forestry, Wildlife and Environment, 2 (2): 214-220.

Tembe, E. T., Ekhuemelo, D. O. and Joseph, E. O. (2020). Evaluation of Fibre Morphological of Rice (Oryza sativa) Varieties Grown in Makurdi, Benue State, for their suitability in Pulp and Paper Production (Eds., B. O. Agbeja, O. V. Oyerinde, J. A. Olusola and O. S. Olaniran) Proceedings of the $3 \mathrm{rd}$ Annual Conference of the Commonwealth Forestry Association, Nigeria Chapter, Federal university of Technology, Akure, Nigeria 06 - 11 June, 2020, Pp. 36-41.

Uchendu, C. N. and Isek, T. (2008). Antifertility activity of aqueous ethanolic leaf extract of Spondias mombin (Anacardiaceae) in rats. African Health Sciences, 8 (3): 163-167

Usta, M. and Eroglu, H. (1987). Soda-Oxygen Pulping Rye Straw. In: Non-wood plant fibre conference. Washington DC. TAPPI press, progress report. 18: 113-118.

Xue Zhang, F. C., Sun, R. C. and Lu, Q. (2006). Anatomy, ultrastructure and lignin distribution in cell wall of Caragana korshinskii. Industrial Crops and Products, 24: 186-193.

(C)2021 This is an Open Access article distributed under the terms of the Creative Commons Attribution 4.0 International license viewed via https://creativecommons.org/licenses/by/4.0/ which permits unrestricted use, distribution, and reproduction in any medium, provided the original work is cited appropriately. 